after the liberation of Poland in 1919 he returned to Warsaw, where he was appointed to the chair of experimental physics at the University, a position he held until his death. When he took office the Physics Department was practically non-existent; but within a few years he built it up into one of the most up-to-date and best-equipped institutions for research and teaching on the Continent of Europe. $\mathrm{He}$ also created a very large and active school, from which have come many of the present leading physicists in Poland.

During the Second World War, the Physics Institute at Warsaw was almost completely annihilated; most of the equipment was taken away to Germany and the buildings seriously damaged. Undaunted, Prof. Pieńkowski carried on with teaching and scientific activities in the underground University. Immediately the War ended, he began to rebuild the Institute, and despite difficult conditions he managed to bring it back to its former splendour.

His research work was mainly concerned with spectroscopy and photoluminescence; he was particularly interested in molecular structure, in which work he also employed X-ray spectroscopy. Later, he developed an interest in nuclear physics and installed in his Institute the first proton accelerator in Poland. Plans for the building of other accelerators had to be abandoned because of the War; but he encouraged work on nuclear physics and cosmic rays and has sent some of his most promising pupils to study in laboratories in Great Britain.

Apart from research and teaching, Prof. Pieńkowski took a very active part in the organization of science in Poland. For several years he was rector (vicechancellor) of the University of Warsaw, and he resumed this office immediately after the War with the formidable task of rebuilding the University from the ruins. He also took a leading part in the work of the Polish Academy of Science and in recent years was put in charge of its Physics Section, which included the development of atomic energy.

All these outside activities did not diminish his devotion to his own Institute, in which he took the greatest interest and where he was revered by every worker. His was the rare personality which combined a genius for organization and exceptional administrative skill with a remarkable talent for teaching and a youthful zeal and enthusiasm for scientific investigation.

$$
\text { J. Rotblat }
$$

\section{Mr. T. H. Withers}

Thomas Henry Withers, an authority on fossil crustaceans, died on October 2 at Bournemouth, where he had been living since his retirement in 1944 from the staff of the British Museum (Natural History). Born in London in 1883, he became in 1898 a boy attendant in the Geological Department of the Museum, where his natural ability and enthusiasm soon received encouragement from $F$. A. Bather, who eventually, in 1925, established him on the scientific staff.

In 1910 Withers published the first of a long series of papers on fossil cirripedes. Among these contributions were extensive accounts of the cirripedes of the Rügen Chalk (1923) and of New Zealand (1924); but at an early stage in his career he had planned monographic account of the whole group, which had not been revised since Darwin's day.
Starting with the Palæozoic, he was able to show that certain problematical organisms (including Turrilepas), then usually referred to the cirripedes, were in fact not arthropods at all, but belonged to an isolated group allied to the echinoderms which he named, in a volume published by the Trustees of the British Museum (1926), the Machaeridia. His "Catalogue of Fossil Cirripedia" appeared in three volumes: the first, on Triassic and Jurassic forms, in 1928; the second, on the Cretaceous, in 1935 ; and the third, on the Tertiary, in 1953, just over a century after the appearance of Charles Darwin's monograph. In 1851 Darwin knew only four Tertiary species; Withers dealt with ninetythree, no less than forty-three of which he had himself instituted. He was interested, however, not so much in the mere description of material as in the phylogeny of the various forms and in the evolutionary significance of structural changes. The same approach inspired his studies of Mesozoic crabs, in which he discussed the origin and evolution of the Brachyura.

Although hampered by ill-health after his retirement, Withers continued his scientific work to the end, and at the time of his death had almost completed an account of the cirripedes for a forthcoming treatise on invertebrate palæontology.

W. N. EDWARdS

\section{Dr. H. E. Ives}

Dr. Herbert Eugane Ivas was the distinguished son of a distinguished father. Born in 1882 in Philadelphia, he had his early education in physics at the University of Pennsylvania, followed by two years at Johns Hopkins University as a Fellow. He worked in turn at the U.S. Bureau of Standards, the National Electric Lamp Association, the United Gas Improvement Co., the Western Electric Co., and finally at the Bell Telephone Laboratories. He had one break, as an officer in the United States Army in 1918, when he was in charge of research on aerial photography, and another during 1941-45 when he was head of a section of the National Defense Research Committee.

He was a member of many scientific societies, and served as president of the Optical Society of America and of the American Numismatic Society. $\mathrm{He}$ was a corresponding member of the British Illuminating Engineering Society, and a Fellow of the Physical Society, before which he delivered the Thomas Young Oration in 1933. In the same year he gave the Traill-Taylor Memorial Lecture before the Royal Photographic Society. Among other honours he received the Frederic Ives Medal (founded in memory of his father) from the Optical Society of America.

Ives's work was mainly in the field of applied optics, but in this field he roamed widely. His earliest work concerned colour photography, and this led him to examine the efficiency of illuminants, a subject to which he frequently returned. The width of his approach is shown by the inclusion of the firefly among illuminants. In studying illuminants, he improved the practice of photometry, showing among other matters the origin of some discrepancies found in flicker photometry. In considering illumination, it was natural to him to study spectrophotometry and various receivers of radiation such as photoelectric cells, thermopiles, and-as a special case-the eye. 